\title{
Article
}

\section{Enacting children's citizenship: developing understandings of how children enact themselves as citizens through actions and acts of citizenship}

Larkins, Cath

Available at http://clok.uclan.ac.uk/6759/

Larkins, Cath ORCID: 0000-0003-2999-6916 (2013) Enacting children's citizenship: developing understandings of how children enact themselves as citizens through actions and acts of citizenship. Childhood, - (-). pp. 1-15. ISSN 0907-5682

It is advisable to refer to the publisher's version if you intend to cite from the work. http://dx.doi.org/10.1177/0907568213481815

For more information about UCLan's research in this area go to http://www.uclan.ac.uk/researchgroups/ and search for <name of research Group>.

For information about Research generally at UCLan please go to http://www.uclan.ac.uk/research/

All outputs in CLoK are protected by Intellectual Property Rights law, including Copyright law. Copyright, IPR and Moral Rights for the works on this site are retained by the individual authors and/or other copyright owners. Terms and conditions for use of this material are defined in the policies page. 
Childhood

\section{Enacting children's citizenship: developing understandings of how children enact themselves as citizens through actions and Acts of citizenship.}

\begin{tabular}{|c|c|}
\hline Journal: & Childhood \\
\hline Manuscript ID: & CHD-11-0100.R3 \\
\hline Manuscript Type: & Original Manuscript \\
\hline Keywords: & $\begin{array}{l}\text { Children's Citizenship, Acts of Citizenship, Participation, Agency, Social } \\
\text { Justice }\end{array}$ \\
\hline Abstract: & $\begin{array}{l}\text { Children have an unsettled relationship with the status of citizenship, being } \\
\text { given some rights, responsibilities and opportunities for participation, and } \\
\text { being denied others. Yet if citizenship is conceived of as a practice, children } \\
\text { can be firmly seen as citizens in the sense that they are social actors, } \\
\text { negotiating and contributing to relationships of social interdependence. } \\
\text { This article develops understandings of children's agency in citizenship and } \\
\text { some of the different ways in which children's actions enact them as } \\
\text { interdependent citizens. It presents one aspect of the understanding of } \\
\text { citizenship generated from research by six groups of marginalised children, } \\
\text { aged 5-13, in Wales and France. Synthesising the research groups' } \\
\text { descriptions of activities they associated with the component parts of } \\
\text { citizenship with citizenship theory, these children can be seen to engage in } \\
\text { actions of citizenship that include making rules of social existence, } \\
\text { furthering social good and exercising freedoms to achieve their own rights. } \\
\text { Their activities also transgress the boundaries of existing balances of } \\
\text { rights, responsibilities and statuses, through their (mis)behaviour, in ways } \\
\text { that can be interpreted as Acts of citizenship. In children's everyday } \\
\text { activities, however, the distinction between actions and Acts of citizenship } \\
\text { can at times be blurred. This is because recognizing aspects of children's } \\
\text { practices as citizenship is a challenge to dominant definitions of citizenship, } \\
\text { and claims a new status for children. Exploring children's citizenship in } \\
\text { these ways has potential for widening understandings of participation and } \\
\text { appreciating broader aspects of children's agency in citizenship. }\end{array}$ \\
\hline
\end{tabular}

\section{SCHOLARONE \\ Manuscripts}


Children are citizens. This assertion, although not new, remains contentious (Lister, 2007). When citizenship is seen as a status related to national membership or political voting rights, although children are rights holders according to the UNCRC (1989), the extent to which this conveys citizenship upon children is debateable. However, citizenship is not only a status. Indeed focusing on contractual and universal status models of citizenship reinforces exclusion. Difference-centred, relational approaches to children's citizenship, that recognise and value children's practices and differences, are therefore necessary (Cockburn, 1998; Moosa-Mitha, 2005). Exploration of children's role as social actors is a good starting point for developing such understandings of citizenship (Jans, 2004), as is listening to children's views on what their citizenship should mean (Stasiulis, 2002). This article develops difference-centred relational understandings of children's agency in citizenship, drawing on research with six groups of marginalised children, aged 5-13 and living in Wales and France. Synthesising the groups' perspectives on aspects of citizenship with existing theory, the research produced a theoretical lens for understanding some commonalities and difference in their citizenship experiences and aspirations and explored the relevance of Europe. This article reports one aspect of the theoretical lens developed, related to the ways in which children are enacted as citizens through their actions. It draws particularly on citizenship theories of Arendt (1998), Lister (1997), Isin (2008) and Neilsen (2008).

\section{Existing Understandings}

Citizenship is a legal and social status, and a set of 'juridical, political, economic and cultural' practices (Turner, 1993: 2). Citizenship determines 'how economic and cultural capital are redistributed and recognised within society' (Isin \& Turner, 2007: 14). It comprises 'relationships between rights, duties, participation and identity', these elements being defined differently from different political perspectives (Delanty, 2000: 9). Lister (2007a: 699) argues that comprehensive definitions of children's citizenship must consider the ways children live 'membership, rights, responsibilities and equality of status'.

Dominant contractual and universal definitions of citizenship exclude children from the status of citizenship on the basis that, as not-yet-adults, they do not have the competences associated with citizenship, such as rationality and independence (Cockburn, 1998; Moosa-Mitha, 2005). There are not, however, clear-cut differentiations between childhood and adulthood competence, dependence and vulnerability (Ben-Arieh \& Boyer, 2005; Cockburn, 1999; Wyness, 2000). All children are not more vulnerable than all adults (Ben-Arieh \& Boyer, 2005), and adults too need protection in some times and places (Cockburn, 1999). All definitions of citizenship have to acknowledge that self-sufficiency is an illusory goal in most societies and that the scope for self-direction is limited by contexts of social living; adults and children can both be seen to live in relationships of social interdependence (Cockburn, 1998, 2005).

Some authors (Ben-Arieh \& Boyer, 2005; Cohen, 2005; Liebel, 2008; Lister, 2007a; Moosa-Mitha, 2005; Stasiulis, 2002), suggest children are citizens in some ways, because in relationships of social interdependence, they live and negotiate the practices and statuses of holding rights, exercising responsibilities and participating 
in social life. However children's status as citizens is also undermined, by social welfare interventions and laws that apply levels of control, limitations in rights and restrictions in access to certain public spaces, that that are not imposed on adults (Cockburn, 1998). Cohen (2005: 222) uses the term 'semi-citizenship', to show that children 'are citizens by certain standards and not by others'.

Relational and difference-centred approaches are proposed as an alternative to evaluating the extent of children's citizenship against an abstract definition of citizenship status that does not apply to marginalised adults or children (Cockburn, 2005; Lister, 2007a; Moosa-Mitha, 2005). Relational and difference-centred approaches acknowledge that individuals are specifically socially and historically situated, but do not judge differences as meaning 'less than' (Moosa-Mitha, 2005: 378). Rather than passive recipients of the legal status of citizenship, conveyed by nation-states, in difference-centred approaches citizens define citizenship through practices and in relationships with others and communities (Moosa-Mitha, 2005).

The relational space in which children's citizenship is practiced includes the home, neighbourhood, school and leisure facilities plus occasional contact with figures of authority in peripheral zones (Jans, 2004). Cockburn (2007) suggests citizenship exists in groups of collectivities and intermediate spaces between public and private spheres. Locating citizenship in these spaces moves children's citizenship from discussions of state-individual or state-civil society interactions, to consider more horizontal dimensions of relations within civil society (Roche, 1999). Whilst children have rights and responsibilities, conveyed upon them by national law and international conventions, these are realised in the spaces of interpersonal, as well as person-state, relations (Roche, 1999).

In these relational spaces, children are participating social actors (Jans, 2004). Children exercise agency and contribute, for example, to domestic and national economies and interpersonal relationships, in homes, schools and businesses (Alderson, 2010; Morrow, 1996, 2008; Qvortrup, 2008). Children and young people also participate as social actors in local, national and international organisations working for change (Liebel, 2008; Stasiulis, 2002).

Not all agency is citizenship, but the relationship between the two is fundamental (Lister 1997: 39). The question therefore arises as to through which practices are children citizens? In some discussions children's citizenship agency has been intertwined with participation (Moosa-Mitha, 2005), especially since Hart's (1992) ladder equated increasing levels of influence over decision-making with movement closer to the attainment of citizenship. A focus on participation as decision-making or influence over systems remains important, to ensure political mechanisms become responsive to children's demands (Wall, 2012). But in European contexts, youth participation tends to also include taking part in collective activities focused on social integration (Loncle, 2008). Learning from a majority world perspective, Thomas and Percy-Smith (2010: 2) suggest that meeting one's own needs can be a form of participation, concerned with 'survival, [children] meeting their basic needs and contributing to their family and community, as [much as] it is about choice and selfrealisation'. Rather than defining citizenship agency as participation, this article 
explores the activities children associate with citizenship and argues a fuller framework for understanding children's social and political agency in citizenship is needed.

\section{Research Process Participants}

This research developed understandings of the citizenship components: rights, duties/ responsibilities, participation, status and membership/belonging (Delanty, 2000; Lister, 2007a), with children aged 5-13. Young people's perspectives on citizenship vary according to whether they are 'insiders' or 'outsiders' (Lister et al., 2003) and this research had a particular focus on developing an inclusive definition of citizenship and relating this to European policy. Existing research in Europe had focused on the views of older 'insider' young people, I therefore sought participation of groups of younger and marginalised children, selected to mirror significant exclusions as identified in the EU children's rights strategy (Commission, 2006). All groups were located in areas experiencing significant levels of poverty.

Participants were recruited in two countries, Wales and France; a choice based on the language skills of the researcher (in English and French) and the wish to relate at least two EU member states with different theoretical traditions on citizenship. Key differences between the two traditions are that in France citoyenneté, strongly associated with the nation state and 'La République', requires citizens to detach themselves from any community allegiances, downplaying differences in order to express themselves as individuals in a formal political arena. In the UK, in contrast, citizenship is associated with social rights, the welfare state and community engagement (Neveu, 2004; Vanhoenacker, 2011). Although anthropological approaches in France do explore lived practices of citizenship (Neveu, 2004), the link between citizenship and nation remains more fixed in France than Britain (Vanhoenacker, 2011).

The participants in Wales were the Disabled Children, Gypsy Travellers, and Young Carers groups. In France they were Refugee, Looked After and Minority Ethnic groups. The Looked After group were all living in alternative residential care, with differing levels of contact with their birth families. The Refugee group members had not been granted legal refugee status at the start of the research and were in a process of asylum seeking: during the research some group members' statuses changed. These two groups participated in the research in the places where they were living: a children's home and a refugee reception centre. One group, the Gypsy Travellers, took part in the research in school. The other three took part in the research whilst at clubs or a play scheme. Group size varied between four and sixteen members, the smallest being the Disabled Children group and the largest being the Young Carers group. The 55 children were aged $5-13$ years. $51 \%$ of them lived in Wales and 49\% in France. 65\% were girls and 35\% were boys.

The recruitment of participants paid attention to ethical considerations, as outlined by Alderson (2005), Morrow (2005) Punch (2002), particularly concerning children's 
freedom to consent and confidentiality. Invitations to participate were given to established groups within the selected geographical areas, where host organisations would commit to support action by and on behalf of the children's research goals. These host organisations gave research information sheets and invitations to the children they worked with. Children in all of the groups approached expressed interest in participating. They were then given parental information and either consent or assent forms, depending on advice from host organizations. At our first meeting I offered children further opportunities for information exchange and gained their signed consent to participate. Fluid consent, the freedom to withdraw from the research at any time, was assured by making other activities available at the same time as the research sessions. During the research process confidentiality was limited by local child protection procedures. The research group members chose their own pseudonyms, or asked me to choose a name for them.

\section{Methodology and methods of fieldwork}

These six groups generated qualitative data through participatory reflective action, drawing on the methodologies of Freire (1973). Namely, the groups were given generative words, then cycled through processes of exploring their own experiences and meanings, reviewing the understandings they co-created and taking action for change in their own understandings and environments. The cycles of reflection were facilitated by a participatory approach (Boyden \& Ennew, 1997). Entirely child-led research was not possible in this context, as I had set the initial focus on citizenship and Europe. Instead I aimed to enable participants' self-direction over the maximum range of research processes possible (Franks, 2011). The groups choose their own methods and themes, analysed their own data and edited their own research reports and videos.

The groups met with me to do research for four to six sessions, of between an hour and three hours each. Sometimes we held further sessions to edit and agree their video and reports. At the first session I provided resources and activities to facilitate groups to develop a range of different methods, including art materials, games, voice recording, photo and video equipment. Each group took then control of the direction and content of the research at different speeds; the Young Carer group set their own questions and created their own methods on the first night we met. The data collection activities the six groups created were video and audio interviewing, performance, drawing, group discussions and site tours. The children's research group members sometimes got consent to photograph, film and interview their families, friends and workers during their video and photo tours, and these extra contributions became part of the groups' data. At the fourth or fifth session with each group I asked how citizenship should be distributed and we discussed the meaning of the word 'Europe'.

To facilitate groups' interaction with, ownership and coding of data, I provided them with their data from previous sessions in various forms. Verbal research data was made available as entire transcripts, coded and grouped data, and just codes (extracts of their text on small cards, using wording agreed by the group). The visual research data was made available to each group through photographs and on DVD edited according to their instructions. In each session the groups reviewed the 
data they had previously produced, sometimes prompted by me asking questions such as 'What does this mean?'. They then applied codes to sections of their videos or text and chose what themes to pursue in greater detail. At the end of our research they chose the content of their own group research reports and videos, which four groups then used to lobby for and sometimes achieve change in their local environments.

\section{Further data analysis and theory building}

Following the fieldwork, I reviewed and coded the few sections of their work which they had not had time to code themselves. I then analysed their work using a grounded approach to critical realist theory building to explore possible causal mechanisms and to reflect on the interplay of agency and structure (Oliver, 2012). This involved developing central process categories (Corbin and Strauss, 2008), and then a metatheory by exploring existing accounts and their deficiencies (Cruickshank, 2003). In relation to agency, I explored different dimensions of the activities that emerged from the groups' codes and then explored differences within these with reference to existing academic literature on citizenship practices. I then tested the explanatory power of the emerging theory, by using the analytical framework I had developed to explore whether it provided insights into causal mechanisms linking the Children's Research Group's goals for change and EU policy. This testing led to revision of some categories and clarification of some of the overlaps between them.

The eventual framework I identified, through which the Children's Research Group members experienced citizenship, comprised five processes: domains, attitudes, actions, resources and constraints. These intertwined to reveal how children held and requested attitudes that can be associated with citizenship, and exercised agency through their actions; creating, using and distributing resources, accepting and challenging constraints. At the same time these children encountered structures which imposed constraints and provided resources, sometimes expressed through the actions and attitudes of institutions and other actors. My understanding of the different ways the Children's Research Group members engaged in only one of these processes, actions, is detailed in the rest of this article. Their understandings of the relevance of Europe are reported elsewhere (Author, 2011).

\section{Language and Limitations}

This work is informed by children with a range of experiences, but remains firmly fixed in my position as a researcher educated in politics and sociology within the UK. My interpretation of the children's perspectives aims to be a 'good enough' attempt to grasp at meanings by reflecting on tensions across social positions, cultural and language barriers (Temple et al., 2006). To this end, I developed generative words associated with citizenship from a review of empirical research with children and young people, in English and French. Following Redmond's (2003) advice on cross national research on childhood, local researchers were recruited, to generate understandings about their own cultural contexts and constructions of childhood. In this case the researchers were children. I worked with the research groups' data in their original languages during the analysis, but in this article I paraphrase in English all of the Children's Research Group members' words. The theoretical literature used 
in relation to actions, and the citizenship process which I explore in this article, was entirely in English, although this literature also influences French language writing on citizenship. As in all critical realist theory building, my analysis therefore remains provisional and open to revision and development. To extend differentiated understanding of children's agency in citizenship, further research is therefore needed with other groups of children and exploration of French theory on citizenship and agency remains crucial.

\section{Findings}

As an introduction to the understanding of actions that emerged from my analysis of the Children's Research Groups' work, I describe below an overview of the groups' key targets for change which they highlighted in their research reports and I list the activities in which I identified their agency. I then explore ways in which these may be seen as actions of citizenship (broadly contributing to dominant definitions of social good); and Acts ${ }^{1}$ of citizenship (transgressing established norms to rebalance distributions of rights, responsibilities and status).

\section{Overview}

The Gypsy Traveller group report asked for an end to racism, improved conditions on Traveller sites and more resources at school. The Young Carers' main target for change was to increase understanding of the contributions they make to the care of others, and for the weight of their responsibilities to be recognised by teachers.

They also asked for more power, voice and choice. The Disabled Children made very few demands for change, although they wanted more time at their play scheme. The Looked After group asked for more opportunities to go home, for children to stop fighting and falling out with each other in their children's home and for people to not shout in meetings. The Minority Ethnic group wanted changes at their homework club, so that there were more opportunities for play; changes in rules at school; and more money, food and housing for people in need. The main focus of the Refugee group's discussion was housing and a long-term home. They also wanted to change the situation of children and families in refugee reception centres, so that they are not shut in and can go wherever they want.

In their discussions, all of the Children's Research Groups mentioned activities that I have categorised in the following ways: contributing, influencing, making safe, communicating, caring, doing education, playing/association, creating self/space and (mis)behaving. Some groups also mentioned travelling or relaxing. For example, children in the Looked After group created resources, and shared their resources with each other, so that they had posters to put on their walls. I categorised this as overlapping activities of contributing and creating space. In a second example, Nathan, in the Disabled Children group, negotiated more turns on a mud slide by communicating in gestures, then achieved more turns than he had negotiated, by continuing going down the slide five more times. I categorised these as activities of influencing, communicating, playing and (mis)behaving.

\section{Actions of citizenship: Negotiations of rules and construction of self} I took theories of action in citizenship that allow an expanded notion of where citizenship can be located as a starting point for theory building from the groups' 
work. Arendt (1998: 198) sees citizenship as located in space that 'arises out of acting and speaking together', that is, space that 'lies between people living together for this purpose, no matter where they happen to be'. For her, citizenship action is also a practice through which the self is created and revealed, by appearing to others in the negotiations of social existence.

Everyday practices of communicating and influencing to negotiate social coexistence appear to readily fit with this definition. For example, members of the Young Carers Group described how they communicated with each other, in a committee which ran their peer led youth group. This committee influenced decisions about what opportunities and resources were made available to group members.

Arendt's focus on appearing to others might also provide a way of understanding the activity of 'creating self' as an action of citizenship, when this combines with negotiation of rules of social coexistence. For example, three Minority Ethnic group members discussed their rules and roles within the space of their research workshops. Their heated discussion, at the end of the first session, resulted in the drafting of a rule which was unanimously voted in at our second session: namely, that everyone should have a role in the research. This process of rule negotiation during the research was perhaps particularly significant and constructive of a sense of self, for these group members, as they described this being the first time they had had the opportunity to set their own rules.

Arendt's understanding of citizenship action does not, however, fit with all activities the groups described. For example, Gypsy Traveller group members talked about developing their sense of identity, and feeling proud, through actions of helping others and looking after themselves, being part of a Gypsy community, and taking part in certain traditional cultural activities. Arendt's definition of citizenship action also does not accommodate other activities which all the groups discussed, such as caring and doing education.

\section{Actions of citizenship: Social Contributions}

Activities of caring that do not correspond to Arendt's (1998) definitions of action, appear related to her definition of labour, which concerns bodily biological processes of survival. All six Children's Research Groups discussed activities of this kind: caring for and helping parents, workers or other children through harvesting food, shopping, laying the table, washing up, cooking, giving money and personal care. These activities could be social contributions in relationships of interdependence with their friends, families, people they live with and neighbours. Some activities also contributed to the survival of people not personally known to them, such as when group members harvested food or raised money that was passed on to others outside their acquaintance. All groups also described elements of social contribution when they were doing education. Although this was sometimes of personal benefit, they also described helping others and having to do work set by teachers. These social or familial contributions have resonance with Arendt's (1998) description of work that is engaged with material things and not freely undertaken. 
Although Arendt does not associate work or labour with citizenship, previous research with young people in the UK has repeatedly included working as part of definitions of what makes a good citizen (Lister et al. 2003). Lister (2007a) and Qvortrup (2008) also argue that activities of caring and doing education are contributions by child citizens. The argument that caring can be citizenship, challenges a formal political understanding of citizenship (Lister 2007a). An action may be seen to constitute social citizenship if it contributes to social benefit, such as towards securing the survival of each living generation of citizens (Pateman 1992 in Lister 1997). Social contributions of caring, although they may take place in what have been termed 'private' spaces, may also be political (Kershaw 2005 in Lister 2007b). Lister therefore suggests that the key determinant of whether or not an action constitutes citizenship should be what a person does and with what public consequences, rather than where they do it' (Lister, 2007b: 57).

At first glance the Children's Research Groups activities of playing, (mis)behaving, travelling and relaxing appear not to be actions of citizenship in either of the two senses outlined above. In some of these activities, however, groups described social contributions to relationships of interdependence. For example, Gypsy Traveller, Refugee and Disabled Children's Research Group members talked about playing with other children as ways of making other children feel included. It could also be argued that play is of social benefit because through play children contribute to their own health and competences. Just as has been claimed of education, play equips children with skills useful for future economic contribution and their current ability to keep themselves and others safe.

More often, however, the Children's Research Groups' members discussed playing, travelling and relaxing for their own individual benefit. Might activities of personal benefit be citizenship actions?

\section{Actions of citizenship: Freedom to enact individuals' own rights}

The research group members described achieving personal benefit through some aspects of playing, creating space, travelling, relaxing, communicating, influencing, caring and doing education. For example, in a pair interview, Gypsy Traveller group member John described achieving his right to play, on his own, in the woods. This isolated action involved activities of playing, creating space and making himself safe in a tree house. The importance of John enacting this right to play may have been particularly significant, because his research group identified the need for the right to somewhere safe to play without experiencing racism. A second example of an action of personal benefit came from the Looked After children group, who talked about exercising the right to silence, in an attempt to influence decisions made about where they live.

These actions, that further individual gains, are means by which members of marginalised groups challenge some structural oppressions associated with racism and generation; however they remain claims to socially agreed rights. These actions might be seen as the exercise of freedom to follow self-interest, within the confines of the law, which Faulks (2000) suggests is fundamental to liberal citizenship theory. Actions of self-sufficiency in achieving socially acknowledged rights might also reflect 
neo-liberal conceptions of active citizenship, which Kennelly and Lewellyn's (2011) research with young people suggests comprises actions and choices of law-abiding people, geared towards increasing individual's own success and reducing their demands on state provision.

Children's activities of (mis)behaviour might then also be citizenship actions, to the extent that (mis)behaviour can fulfil socially agreed rights that are being denied by external constraints. For example, a video recorded by Refugee group member Maximo, showed a group of boys disobeying the Director and enabling their right to play with a worm by going outside the fence of the refugee centre. As they were living in a reception centre for asylum seekers, this could be seen as refugee children, in the face of the structurally confined access to space, achieving the right to play, as defined by Article 31 of the UNCRC (1989). But what of actions that go beyond existing definitions of rights?

\section{Acts of citizenship: transgression of boundaries}

On some occasions, the Children's Research Group members described activities that might be termed (mis)behaviour, because they transgressed the boundaries of existing norms of appropriate behaviour and rights. For example, Looked After, Young Carer and Minority Ethnic group members described how they broke rules at school, to achieve what they described as fairness. Activities such as these may be described as Acts of citizenship (Isin, 2008; Neilsen, 2008). Acts of citizenship are distinct from the actions of citizenship identified above, because they do not contribute to citizenship in currently accepted ways. Acts of citizenship claim shifts in rights and responsibilities, new distributions of resources or a new political status that stretch beyond existing boundaries, bringing 'into being new actors as activist citizens (claimants of rights and responsibilities) through creating new sites and scales of justice' (Isin, 2008: 39). Acts dispute how social goods and attitudes are 'shared, cared for, encouraged, protected or transformed, disciplined, outlawed, abandoned' in a specific time and place (Neilsen, 2008: 268).

Isin (2009) gives three elements as key to understanding Acts of citizenship. First, Acts create a scene of 'performance and disturbance' (2009: 379). Rather than following existing scripts of citizenship (such as voting or paying tax), Acts that remain political because they relate to more than two actors, use new forms, technologies or practices (Isin, 2008). For example, Minority Ethnic group members disturbed the established order at school, and drank water during class. They asked for permission but it was not given, even though the teacher herself was drinking. They then drank anyway. In this instance, the dispute is articulated through secretly drinking, a performance not normally associated with being political. It was political because it involved a range of actors, the pupils, the teacher and the school rules. The Act claimed greater rights, for these children to quench their thirst, and less disparity in status between the pupils and teacher.

Isin's (2009: 381) second key principle states 'acts produce actors that become answerable to justice' but he does not state a given standard of justice to which Acts 
are answerable. Questions of limits to justice and contexts of answerability may arise from this, for example as to whether theft by a group of deprived children or assassination by a terrorist, constitute Acts of citizenship. Isin does imply some limits, as some Acts enact actors as activist citizens, whereas others enact actors as outsiders or aliens (Isin, 2008). Neilsen (2008: 268) imposes the limit that although Acts of citizenship may go beyond the law, they remain assertions of justice; they must 'improvise creative but also enduring and convincing arguments for justice', be situated in the specific moment of the Act, and not be exclusionary. The idea of limits is also present in the Research Groups' data, as they did not see all their (mis)behaviour as justified. Regarding answerability, Isin (2009) notes that actors may not articulate the reasons why they act, but that those who view and interpret an Act ascribe qualities, based on the grounds for an Act and its consequences. An Act may then acquire its meaning for different audiences in different ways at different times. Theft by a group of deprived children may, for example, may be relatively hidden and answerable only to fellow children as the act occurs. It may not until later be known to parents, police or more distant observers, through children's communication or other forms of revelation.

Exploring answerability to justice within the Minority Ethnic group example, their Act created actors who were answerable to justice, the answerability to justice of the Act being interpreted when it was revealed to different publics at different times. It was a claim to inclusionary justice made in front of some children at the time of the Act; made to other children and the researcher during the fieldwork; and, to a wider public through the dissemination of their research findings. In each instance, they gave the grounds for drinking as that it was fair, as the temperature in the class at that moment was high and the teacher was allowed to drink. The consequence of their Act was to include more people in the right to drink.

Isin's third key principle reinforces that 'acts of citizenship do not need to be founded on law or enacted in the name of the law' or responsibility (2009: 382), but that acts create different kinds of political actors, namely 'activist citizens', claiming extensions of justice; contrasted with 'active citizens', whose forms of being political conform to current social expectations of citizenship behaviour (Isin, 2008, 2009). Acts of citizenship, then, are those actions through which individuals or groups challenge the existing relationship they have with citizenship and indeed strive to redefine what citizenship means.

Applying Isin's three key elements to another example from the fieldwork, Young Carers group members' descriptions of a scene in which they disrupted teachers' expectations and school rules may be seen as an Act of citizenship. They used the performance of stealing a homework sheet. Their Act enacted them as actors answerable to justice in relation to other students, teachers and the school rules. They defended their Act on the grounds that they did not have the time to do their homework because of their caring responsibilities. A consequence was to draw attention to their need for more understanding. It disputed elements of the active citizenship expected of them, with significant responsibilities for both social contributions in school work and in caring for parents and siblings. It enacted them 
as activist citizens, of a citizenship which would give them greater rights to resources such as time and answer sheets, or fewer homework responsibilities.

\section{Discussion}

This research reveals a framework of four ways in which children's agency can be seen as practices of citizenship. Three actions of citizenship, consistent with existing social norms of citizenship and enacting what Isin (2008) terms activist citizens, can be differentiated. Namely:

1. negotiation of rules and creating selves;

2. contribution to social good; and,

3. contribution to the achievement of individual's rights.

The fieldwork also revealed a further aspect of agency that challenges existing norms of what constitutes citizenship, in ways which may be Acts of citizenship (Isin, 2008):

4. transgressing existing boundaries of citizenship to dispute balances of rights, responsibilities and status, enacting activist citizens answerable to justice.

Some tensions remain in this framework as, although Isin (2008) suggest Acts and actions of citizenship are distinct, the line between these is blurred, as recognising children as capable of enacting themselves as current citizens still remains a challenge to dominant understandings of childhood and citizenship. Recognising children's activities of social contribution as actions of citizenship challenges dominant definitions, because it values children's current rather than future contributions to social good. Recognising that children exercise freedoms to enact their individual rights, whether these are rights in the UNCRC or fulfilling appropriate responsibilities of neo-liberal citizenship, challenges notions of childhood dependence and acknowledges how they are at times called upon to fulfil their own rights in the absence of social provision. Demanding recognition of the value and meaning of children's agency in these recognised citizenship activities, challenges definitions of citizenship, and therefore may itself be an Acts of citizenship. Acknowledging that children can enact themselves as holders of rights, through Acts of citizenship hidden from adult view, may challenge the notion that decisions about the nature of children's citizenship are determined by adults.

Further, blurring between Acts and actions of citizenship occurs as different activities may be interpreted differently. Resistance and transgressions at school, for example, are a recurrent and international phenomenon, subject to different interpretations (Devine, 2002; Castro, 2012). Likewise, in two research groups communicating in collective decision-making about youth group leisure activities was not a transgression, it was an action of citizenship consistent with the groups' norms and rules. In a third group, however, collective communication to influence choices about leisure activities was not within the norms of the group setting, and the children's attempts to achieve this were punished. Whether children's activity is judged to be an action or Act of citizenship, then, changes across time and space, according to local and individual decisions about how performances or grounds for acts are judged. 
Mirroring how some authors have argued practices of citizenship might include aspects of caring, I have argued that some aspects of playing, can be seen as practices of citizenship. Not all play is citizenship, not all caring is citizenship. But part of both of these activities may be related to citizenship. Such arguments challenge dominant conceptions of the meaning of citizenship and the relevance and value of everyday practices. Such a challenge is necessary because children's actions have been dismissed as non-political, and their calls for justice thereby ignored. This occurred, for example, when rioting by children in Belfast was described as playful and the political content of this practice ignored (Leonard 2010). As children remain largely excluded from formal political spaces, it is vital to recognise the political content of their agency, wherever and however it is performed.

In contrast to assumptions that children are not citizens because they are not independent, this research confirms that children's practices of citizenship contribute to interdependence. Children's individual and social contributions revealed in this research also show at times their self-reliance, in achieving their own rights or adults' dependence on children's contributions of caring. The extent to which children's citizenship practices consist of actions of individual and social contribution may highlight the impact of neo-liberalism, or economic recession, on children's lives. In the interests of maintaining and recognising interdependence across the generations it remains, then, important to also identify other actors and institutions whose social contributions might assist the achievement of children's citizenship aspirations.

\section{Conclusion}

Citizenship is not only practiced by those children who engage in formal participatory processes negotiating rules of social coexistence, such as through councils, committees, forums and decision making processes. Children also enact themselves as citizens through practices at least as diverse as negotiating rules of social coexistence (wherever this may be), contributing to socially agreed good, and fulfilling their own individual rights. The citizenship practices revealed in the research show that children transgress dominant and local constructions of their citizenship and childhood, contesting the justice of existing balances of rights, responsibilities and status. I interpret some of these as Acts of citizenship. Out of fear of reprisals, many of these challenges to existing balances of rights, responsibilities and status were hidden from adult view and only revealed during this research.

To develop this provisional framework for exploring children's agency in citizenship, further research with children is needed to create safe space in which children may explore whether and how they interpret their practices as citizenship. Rather than comparing children to dominant standards of citizenship or calling all of children's citizenship practices participation, children's citizenship studies could usefully focus on children's everyday practices, and children's interpretation of these. This may generate understanding the different citizenships children aspire to. This is not to deny the importance of participation, but to also value the practices through which 
children do not participate in the citizenship they are offered, but enact citizenship of a different kind.

1 I follow Isin's (2008) protocol and always capitalise the term Acts

http://mc.manuscriptcentral.com/Childhood 


\section{References}

Alderson P (2005) Designing ethical research with children. In Ethical Research with Children. A Farrell, ed., Maidenhead: Open University Press.

Alderson P (2010) Younger children's individual participation in matters that affect them. In Thomas N \& Percy-Smith B (eds) A Handbook of Children and Young People's Participation: Perspectives from Theory and Practice. London: Routledge. Arendt H (1998) The Human Condition: Second Edition. Chicago: University of Chicago Press.

Author Ben-Arieh A \& Boyer Y (2005) Citizenship and Childhood. Childhood 12(1): 33-53 Boyden J \& Ennew J (1997) Children in Focus: A Manual for participatory research with children. Stockholm: Save the Children Sweden.

Castro LR (2012) The 'good-enough society', the 'good-enough citizen' and the 'good enough student': Where is children's participation agenda moving to in Brazil? Childhood 19(1): 52-68

Cockburn T (1998) Children and Citizenship in Britain: A case for an Interdependent Model of Citizenship. Childhood 5(1): 99-117.

Cockburn T (1999) 'Children, Fooles and Madmen': Children's relationship to citizenship in Britain from Thomas Hobbes to Bernard Crick'. International Journal of Theory and Research in Education 10 (4): 65-84

Cockburn T (2005) Children and the Feminist Ethic of Care. Childhood 12(1): 71-89 Cockburn T (2007) Partners in Power: a Radically Pluralistic Form of Participative Democracy for Children and Young People. Children \& Society 21(1): 446-457 Commission (2006) Towards an EU Strategy on the Rights of the Child. COM (2006) 367, 4.7.2006, Brussels: European Commission.

Cohen E F (2005) Neither Seen Nor Heard: Children's Citizenship in Contemporary Democracies. Citizenship Studies 9(2): 221-240.

Corbin J \& Strauss AL (2008) Basics of qualitative research: techniques and procedures for developing grounded theory Thousand Oaks: Sage. Cruickshank J (2003) Realism and Sociology: Anti-foundationalism, ontology and social research. London: Routledge.

Delanty G (2000) Citizenship in the Global Age: Culture, Society and Politics.

Buckingham: Open University Press.

Devine D (2002) Children's citizenship and the structuring of adult-child relations in the primary school. Childhood 9(3): 303

Faulks K (2000) Citizenship Abingdon: Routledge.

Franks M (2011) Pockets of Participation: Revisiting Child-Centred Participation Research. Children \& Society 25(1): 15-25.

Freire P (1973) Pedagogy of the Oppressed. New York: Seabury Press.

Hart R (1992) Children's Participation from Tokenism to Citizenship. Florence: UNICEF Innocenti Research Centre.

Isin EF \& Turner BS (2007) Investigating Citizenship: An Agenda for Citizenship Studies. Citizenship Studies 11(1): 5-17.

Isin EF (2008) Theorising Acts of Citizenship. In Isin EF \& Neilsen GM (eds) Acts of Citizenship. London: Zed Books.

Isin EF (2009) Citizenship in flux: The figure of the activist citizen. Subjectivities 29: 367-388. 
Jans M (2004) Children as Citizens: Towards a Contemporary Notion of Child Participation. Childhood 11(1): 27-44.

Kennelly J \& Llewellyn KR (2011) Educating for Active Compliance: Discursive Constructions in Citizenship Education. Citizenship Studies 15(6-7): 897-914. Leonard M (2010) What's Recreational about 'Recreational Rioting'? Children on the Streets in Belfast. Children \& Society 24(1): 38-49.

Liebel M (2008) Citizenship from Below; Children's Rights and Social Movements. In Invernizzi A \& Williams J (eds) Children and Citizenship. London: Sage. Lister R (1997) Citizenship: Feminist Perspectives Basingstoke: Macmillan. Lister R (2007a) Why Citizenship: Where, When and How Children? Theoretical Inquiries in Law 8 (2): 1165.

Lister R (2007b) Inclusive Citizenship: Realizing the Potential. Citizenship Studies, 11(1): 49-61

Lister R, Smith N, Middleton S, \& Cox L (2003) Young People Talk about Citizenship: Empirical Perspectives on Theoretical and Political Debates. Citizenship Studies 7(2): 235-253.

Loncle P (2008) Pourquoi Faire participer les jeunes? Expériences locales en europe Paris: Harmattan.

Moosa-Mitha M (2005) A Difference-Centred Alternative to Theorization of Children's Citizenship Rights. Citizenship Studies 9 (4): 369-388.

Morrow V (1996) 'Rethinking childhood dependency: children's contributions to the domestic economy'. Sociological Review, 44(1): 58-77

Morrow, V. (2008) Dilemnas in Children's Participation in England. In Invernizzi A \& Williams J (eds) Children and Citizenship. London: Sage.

Morrow V (2005) Ethical issues in collaborative research with children. In Farrell A (ed) Ethical Research with Children. Maidenhead: Open University Press.

Neilsen GM (2008) Answerability with Cosmopolitan Intent: An Ethics-Based Politics for Acts of Urban Citizenship. In Isin EF \& Neilsen GM (eds) Acts of Citizenship. London: Zed Books.

Neveu C (2004) Les enjeux d'une approche anthropologique de la citoyenneté. Revue européenne des migrations internationals 20(3): 89-101

Oliver C (2012) Critical Realist Grounded Theory: A New Approach for Social Work Research British Journal of Social Work 42 (2): 371-387

Punch S (2002) Research with Children: The Same or Different from Research with Adults?. Childhood 9(3): 321-341.

Qvortrup J (2008) Conclusion. In James A \& James AL (eds) European Childhoods:Cultures, Politics and Participation. Basingstoke: Palgrave Macmillan. Redmond M (2003) Cultural and ethical challenges in cross-national research: reflections on a European Union study on child and youth migration International Journal of Qualitative Methods 2(4). Article 2.

Roche J (1999) Children: rights, participation and citizenship Childhood6(4): 475493

Stasiulis D (2002) 'The Active Child Citizen: Lessons from Canadian Policy and the Children's Movement'. Citizenship Studies 6(4): 507-538

Temple B, Edwards R, \& Alexander C (2006) 'Grasping at Context: Cross Language Qualitative Research as Secondary Qualitative Data Analysis'. Qualitative Research 7(4): 10 
Thomas N \& Percy-Smith B (2010) Introduction. In Thomas N \& Percy-Smith B (eds) A Handbook of Children and Young People's Participation: Perspectives from Theory and Practice. London: Routledge.

Turner BS (1993) Contemporary Problems in the Theory of Citizenship.In Citizenship and Social Theory, B. S. Turner, ed., London:Sage.

Vanhoenacker M (2011): Education in a French secular group of scouts: a site to study tensions over citizenship. Citizenship Studies 15(8): 1047-1059

Wall J (2012) Can democracy represent children? Toward a politics of difference.

Childhood 19(1): 86-100

Wyness M (2000) Contesting Childhood London: Falmer Press. 